\title{
Improving the breeding success of a colonial seabird: a cost-benefit comparison of the eradication and control of its rat predator
}

\author{
Michel Pascal $^{1, *}$, Olivier Lorvelec ${ }^{1}$, Vincent Bretagnolle ${ }^{3}$, Jean-Michel Culioli ${ }^{4}$ \\ ${ }^{1}$ INRA, Equipe Gestion des Populations Invasives, Institut National de la Recherche Agronomique, Station SCRIBE, \\ Campus de Beaulieu, 35042 Rennes Cedex, France \\ ${ }^{2}$ Centre d'Études Biologiques de Chizé, Centre National de la Recherche Scientifique, 79360 Beauvoir-sur-Niort, France \\ ${ }^{3}$ Réserve Naturelle des Bouches de Bonifacio, Office de l'Environnement de la Corse, BP 507, 20159 Rondinara, France
}

\begin{abstract}
Breeding success of 5 Cory's shearwater Calonectris diomedea sub-colonies of Lavezzu Island (Lavezzi Archipelago, Corsica) was checked annually for 25 consecutive years from 1979 to 2004. Between 1989 and 1994, 4 ship rat Rattus rattus controls were performed in several subcolonies. In November 2000, rats were eradicated from Lavezzu Island and its 16 peripheral islets (85 ha) using traps then toxic baits. We compare cost (number of person-hours required in the field) and benefit (Cory's shearwater breeding success) of control and eradication. The average breeding success doubled when rats were controlled or eradicated (0.82) compared to the situation without rat management $(0.45)$. Moreover, the average breeding success after eradication (0.86) was significantly $(11 \%)$ higher than after rat controls $(0.75)$. Furthermore, the great variation in breeding success recorded among sub-colonies both with and without rat control declined dramatically after eradication, suggesting that rats had a major impact on breeding success. The estimated effort needed to perform eradication and checking of the permanent bait-station system during the year following eradication was 1360 person-hours. In contrast, rat control was estimated to require 240 or 1440 person-hours per year when implemented by trained and untrained staff, respectively. Within $6 \mathrm{yr}$, eradication cost is lower than control cost performed by untrained staff and confers several ecological advantages on more ecosystem components than Cory's shearwater alone. Improved eradication tools such as hand or aerial broadcasting of toxic baits instead of the fairly labour-intensive eradication strategy we used would dramatically increase the economic advantage of eradication vs. control. Therefore, when feasible, we recommend eradication rather than control of non-native rat populations. Nevertheless, control remains a useful management tool when eradication is not practicable.
\end{abstract}

KEY WORDS: Biological invasion $\cdot$ Eradication $\cdot$ Control $\cdot$ Seabirds $\cdot$ Rattus rattus $\cdot$ Calonectris diomedea

\section{INTRODUCTION}

Since the 1992 Rio Summit, studies devoted to biological invasions have confirmed the initial conclusion of the summit that such invasions induce major economic costs (OTA 1993, Perrings et al. 2000, Pimentel et al. 2000, 2005, Pimentel 2002), have a strong impact on hu- man and veterinary health (MacMichael \& Bouma 2000, Ruiz et al. 2000, Audouin-Rouzeau 2003), and are one of the major sources of global biodiversity loss (Diamond 1989, Wilson 1993, Vitousek et al. 1997, Veitch \& Clout 2002, Hulme 2003; but see Gurevitch \& Padilla 2004, Clavero \& García-Berthou 2005). Moreover, in the last half century dramatic increases in the number 
of biological invasions (e.g. Wilson 1993, Pascal et al. 2006), related to a dramatic increase in trading activity (Cariton 1987, Cariton \& Geller 1993, Ruiz et al. 1997), led Mooney \& Hobbs (2000) to consider biological invasion as one of the major processes of current global changes. The latter authors ranked biological invasions at the same level as climate change.

Biological invasions affect most ecosystems (e.g. Mooney \& Hobbs 2000), but are particularly damaging on oceanic islands. There are 2 main ecological explanations for this: insular trophic webs are simple compared to continental ones (Towns \& Ballantine 1993, Courchamp et al. 2002), and islands host a higher proportion of endemic species than continents (Nunn 1994, Whittaker 1998). Consequently, the extinction rate of native species owing to the effects of invasive species has been notoriously higher on islands than in continental ecosystems (Diamond \& Veitch 1981, Honegger 1981, King 1985, Ceballos \& Brown 1995, BirdLife International 2000).

Although island invaders may belong to any taxon (Towns \& Ballantine 1993, Lever 1994, Courchamp et al. 1999), those that have induced documented species extinctions mainly belong to higher trophic levels (predators and herbivores), and are predominantly mammals. Mammal introductions have been so numerous that very few islands are not affected (Atkinson 1985,1989, Ebenhard 1988, Flux 1994, Vitousek et al. 1997). Rats (Rattus spp.) alone have been introduced to more than $80 \%$ of island groups worldwide (Atkinson 1985) and, although the introductions were mostly accidental, have extirpated many animal and plant species (e.g. Bell 1978, Groombridge 1992). Mediterranean islands provide a good illustration of this phenomenon: more than 2000 yr ago, humans introduced the ship rat Rattus rattus to most islands in the region (AudouinRouzeau \& Vigne 1994). Subsequently, this rodent has strongly affected insects (Palmer \& Pons 1996), vascular plants (Palmer \& Pons 2001), birds (Martin et al. 2000), and endemic mammals (Vigne 1999, Pascal et al. 2006). Mediterranean colonial nesting seabirds have been among the most vulnerable in terms of both distribution and abundance, the level of impact being affected by bird body size, island area and island substrate (Penloup et al. 1997, Martin et al. 2000).

Many islands are sufficiently small and isolated for management of invasive species to be more easily implemented there than on the mainland (Chapuis et al. 1995, Atkinson, 2001, Courchamp et al. 2002). Such management actions must be considered as experiments (Pascal \& Chapuis 2000), but have nonetheless often produced strikingly unexpected results (Simberloff 2001, Pascal et al. 2005), and have enlightened several aspects of evolutionary biology (Sax et al. 2007) that may be of major interest for management.
Two different management options have been used against alien mammals: (1) control (also known as maintenance management), and (2) eradication. All management of invasive rat populations was restricted to population control prior to the first known insular rat eradication in 1952 (Lorvelec \& Pascal 2005). Towns \& Broome (2003) quoted more than 250 insular rat eradications in their 2003 synthesis. A recent review increased this number to 318 out of a total of 332 actions aimed at eradicating rats and mice (Howald et al. 2007). Moreover, the increasing effectiveness of eradication techniques (Taylor \& Thomas 1993, Taylor et al. 2000, Towns \& Broome 2003) has enlarged the extent of eradications in continental (Simberloff, 2002) and insular settings, reaching 12000 ha on Campbell Island, New Zealand (McClelland \& Tyree 2002).

Therefore, rat eradication presently appears to be more limited by finance than by technology. Nevertheless, control continues to be performed in many instances, including situations where eradication is possible. Thus, costs and benefits of both options have to be considered, keeping in mind that control requires continuous action (Hodges \& Nagata 2001), whereas eradication, if successful, is a permanent solution if new introductions are prevented.

Here we undertake a cost-benefit analysis, using as a case study, Lavezzu Island, where the ship rat was recorded in the fifteenth century (Vigne et al. $1994 a, b)$ and was very abundant until recently (Thibault et al. 1987a,b). This rodent strongly affects breeding success of the colonial seabird Cory's shearwater Calonectris diomedea. On Lavezzu Island, like other Mediterranean islands, rat predation on adults or eggs has never been recorded, the rodents apparently affecting 4 to $6 \mathrm{~d}$ old chicks until fledgling (Daycard \& Thibault 1990, Thibault 1995). These effects were recently confirmed by Igual et al. (2006). Howald et al. (2007) briefly discussed the economic aspects of eradication and shared the views expressed by Donlan \& Wilcox (2007) who underlined the difficulties that must be overcome to comprehensively cover the subject. We suggest a way to avoid covering all economic aspects, while allowing rational comparisons by using one simple parameter: time spent in the field to perform management actions. The Lavezzu Cory's shearwater population size and breeding success have been recorded annually since 1979. In past years, rodent control was performed sporadically, but rodents were eradicated from the island during October 2000. This situation provides a unique opportunity to contrast these 2 management strategies and to compare respective cost (time spent in the field to perform control or eradication) and benefit (Cory's shearwater breeding success). 


\section{MATERIALS AND METHODS}

Study site. Lavezzu Island (73 ha) and its 16 peripheral islets (total area $12 \mathrm{ha}$ ) is a Nature Reserve and a part of the International Bonifacio Strait Marine Park within the Lavezzi Archipelago (Corsica) in the Bonifacio Strait, between Corsica and Sardinia (Fig. 1). Lavezzu Island has no cliffs and is flat though punctuated with bare granite eroded masses reaching a maximum height of less than $40 \mathrm{~m}$. Typical dry Mediterranean flora covers the thin sandy soil between the rocky masses. Domestic pigs, goats, sheep, cattle, donkeys and cats, feral rabbits, and synanthropic ship rats were present during the 20th century, and possibly for a long time previously. All but rats were extirpated before the end of the 1990s.

Cory's shearwater. Cory's shearwater (order: Procellariiformes) breeds on northeastern Atlantic Ocean (Macaronesian) and Mediterranean islands (Thibault et al. 1997). The estimated 50000 to 65000 pairs of the Mediterranean population breed at fewer than 150 sites (Thibault et al. 1997), and most of the population is concentrated in a small number of colonies in the Sicily Channel and the western part of the Mediterranean Basin (Zotier et al. 1999). The Lavezzu Island Cory's shearwater population was estimated at 395 to 450 pairs in 1995. These pairs are scattered among 8 permanent distinct sub-colonies. All colonies are located in crevices, many of which are deeply cut into the base of granite masses. Each year between 1979 and 2004, breeding success from laying to fledging

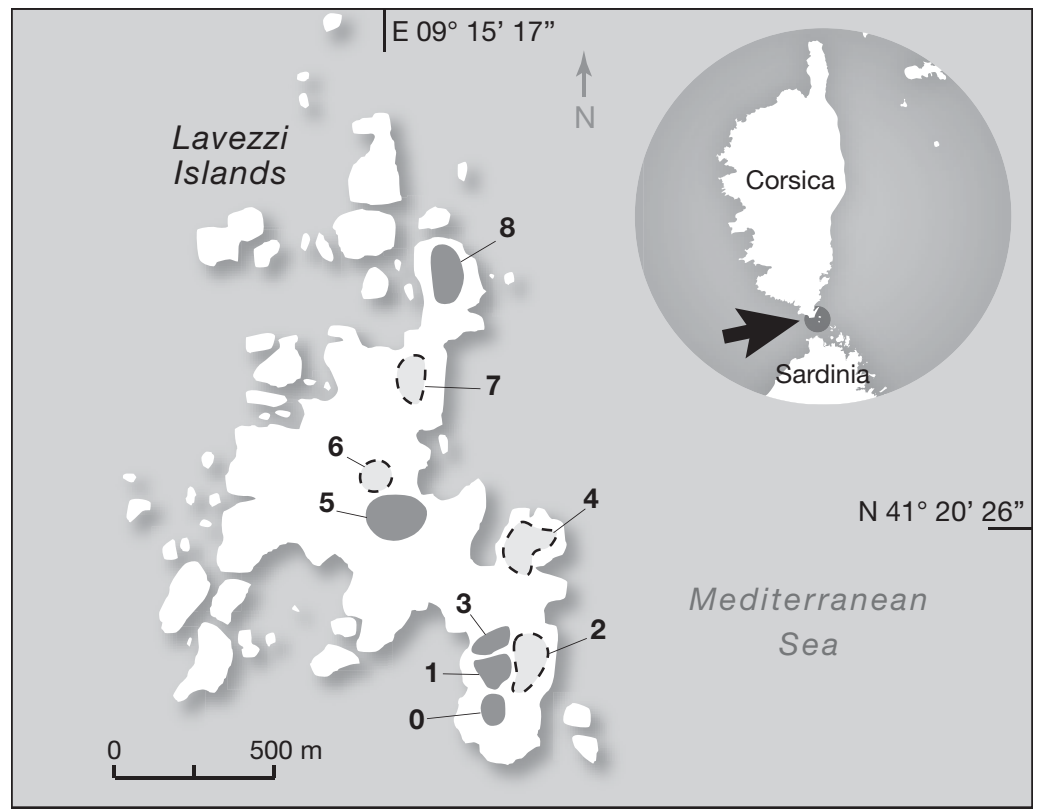

Fig. 1. Lavezzu Island and its peripheral islets. Grey numbered areas show Cory's shearwater sub-colonies. Darker areas indicate investigated and analysed sub-colonies was recorded in 5 to 6 of these sub-colonies (Fig. 1). A single egg is laid per burrow each year (Warham 1996). Egg-laying is synchronised within sub-colonies and between years (Thibault et al. 1997). Incubating birds were therefore checked each year by a single observer on 2 consecutive days between 2 and 26 June. Fledging occurs in October (Thibault et al. 1997), and thus fledging success was recorded over 3 or $4 \mathrm{~d}$ between 20 September and 6 October. We used the presence of a fledgling in a burrow as a proxy of breeding success. On average, 107 Cory's shearwater nests (range: 93 to 181) were checked each year.

Rat management. During all the 1989, 1992, 1993 and 1994 breeding seasons, rat control was performed within 1 to 4 of the Cory's shearwater sub-colonies using toxic pellets (coumatetralyl) inserted in PVC tubes that were checked daily. The number of person-hours allocated to these field operations was recorded daily.

Strategies used to eradicate ship rats were based on those described in Pascal \& Chapuis (2000) for successful eradication of insular Norway rat Rattus norvegicus populations that shared islands with other small native mammal species (Pascal et al. 1996, Lorvelec et Pascal 2005). This method involves the successive use of trapping and toxic baiting. By trapping more than $90 \%$ of the individuals of the target species, samples can be obtained for other analyses such as population genetics (Calmet et al. 2001, Abdelkrim et al. 2005a,b, 2007). In November 2000, 540 trapping-baiting devices were distributed over a $25 \times 25 \mathrm{~m}$ square grid on Lavezzu Island and its 16 peripheral islets. Each device included a live-trap (Manufrance ${ }^{\odot}$ ) and a PVC tube. Traps, baited with a mixture of oat-flakes, peanut butter and sardine oil (Buckner 1957), were checked daily. Rats were euthanized and non-target species released. When the number of trapped rats dropped to zero per day, toxic baits made of wheat covered by an oily bromadiolone concentrate (50 ppm) were inserted in the PVC tubes and checked each 2 to $4 \mathrm{~d}$. Baits and tubes were removed at the end of the operation.

In order to equally share effort between teams during the eradication operation, the total area was split into 6 units (A, B, C1, C2, D and I), 5 for Lavezzu Island, the sixth encompassing all other islets. We assessed time in the field allocated to each unit as 40 personhours for setting the trapping-baiting devices, 12 person-hours for each trap daily control, and 8 person-hours for each daily simple toxic-bait control. 
After eradication, a permanent bait-station system (maintenance system) was set in order to detect eradication failure or newcomer arrival. Checking this system took 4 person-hours. If this maintenance system was routinely checked only every 2 or 4 mo as soon as eradication was considered successful, it was checked monthly during the year following the eradication attempt.

Statistical analyses. As some burrows were out of reach, checking breeding success was restricted to reachable breeding pairs. However, we used burrow rather than pair as the statistical unit in analysis because (1) pair identity can change from year to year, as mate fidelity, although high, is not $100 \%$ (Warham 1996), and (2) burrow number changed from year to year, only the ones that hosted an egg being taken into consideration. We used Generalised Linear Models with binomial error distribution and a logit link function in order to model effect on breeding success $(0=$ no fledged chick; 1 = chick fledged) by independent variables such as rat management (3 classes: no rat management, rat control and rat eradication), year and sub-colony. We checked model over-dispersion, and corrected deviance if necessary using a scaling factor. Because our focus was on the effects of rats on breeding success, only second-order interactions involving rat management were modelled. Two models were compared: before 2000, when rat management only included rat control, and between 1978 and 2004, for comparison between the 2 rat management options. All statistical tests were performed using the SAS 8.0 statistical package.

\section{RESULTS}

\section{Rat management}

During the eradication trapping stage (18 October to 6 November 2000), 1338 ship rats were trapped, all during the first 12 trapping days (6480 trap-nights). No evidence of rats was found at the end of the toxic baiting stage. In October 2001, no rats were caught in the 106 traps that were set for 4 nights $(5 \mathrm{~d})$ in the area where the highest rat density was recorded during the eradication process. Checks for signs of rats were also unsuccessful, thus confirming eradication success. Since November 2000, neither rats nor signs of rat activity have been recorded either on the main island or on islets, and none of the baits in the permanent bait stations have been touched.

A total effort of 510 person-hours was invested in control during 4 yr over the $25 \mathrm{yr}$ period (Table 1). The number of person-hours per sub-colony decreased from 180 to 30 between 1989 and 1994, but
Table 1. Estimation (person-hours) of effort devoted to rat management operations: eradication (year: 2000) and control. For details of the sub-areas see 'Materials and methods'; for 'sub-colonies' see Fig. 1

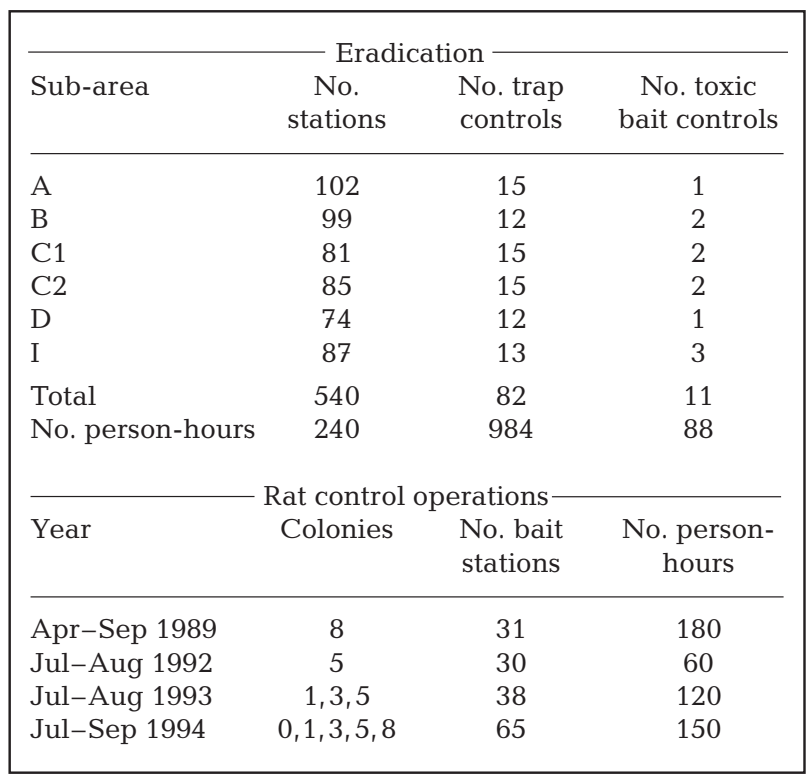

stabilised during the 2 last operations. This variation was linked to increasing ranger experience in rat management. Consequently, we estimated effort, first for untrained staff based on the 1989 value, and second for trained staff based on the 1994 figure, and showed that 240 or 1440 person-hours (trained and untrained staff, respectively) would be required annually in order to control rats in the 8 Cory's shearwater sub-colonies.

The total number of person-hours required to eradicate rats by trained staff was 1312 (Table 1), to which must be added a year of effort for the monthly checking of the permanent bait-station system (48 personhours $\mathrm{yr}^{-1}$ ), for a total of 1360 .

\section{Cory's shearwater}

The number of nests checked per year and per colony is given in Table 2. Breeding success varied greatly among years, and to lesser extent, sub-colonies, presumably in relation to interannual and local variations in rat density and behaviour (Fig. 2). Breeding success before eradication varied significantly among years and sub-colonies (year effect: $\chi^{2}=363, \mathrm{df}=21, \mathrm{p}<$ 0.001; sub-colony effect: $\chi^{2}=168, \mathrm{df}=4, \mathrm{p}<0.001$; interaction: $\chi^{2}=376, \mathrm{df}=84, \mathrm{p}<0.001$ ). This result was the same if data collected after eradication were added. Although the year effect was the most important after eradication, all sub-colonies reached the same level of very high breeding success (Fig. 2). 
Table 2. Calonectris diomedea. Number of Lavezzu Island Cory's shearwater nests checked per year and per sub-colony (sub-colony numbers as in Fig. 1). Bold: values under rat control; bold and italic: values after rat eradication

\begin{tabular}{|c|c|c|c|c|c|c|}
\hline \multirow[t]{2}{*}{ Year } & \multicolumn{6}{|c|}{ - Sub-colony - } \\
\hline & 0 & 1 & 3 & 5 & 8 & Total \\
\hline 1978 & 21 & 25 & 10 & 33 & 20 & 109 \\
\hline 1979 & 24 & 29 & 13 & 53 & 34 & 153 \\
\hline 1980 & 26 & 27 & 11 & 52 & 33 & 149 \\
\hline 1981 & 28 & 28 & 13 & 55 & 37 & 161 \\
\hline 1982 & 24 & 26 & 13 & 57 & 34 & 154 \\
\hline 1983 & 28 & 29 & 15 & 58 & 35 & 165 \\
\hline 1984 & 30 & 27 & 15 & 55 & 26 & 153 \\
\hline 1985 & 31 & 27 & 16 & 59 & 34 & 167 \\
\hline 1986 & 32 & 30 & 16 & 55 & 30 & 163 \\
\hline 1987 & 34 & 31 & 18 & 57 & 29 & 169 \\
\hline 1988 & 34 & 35 & 20 & 56 & 36 & 181 \\
\hline 1989 & 33 & 33 & 20 & 54 & 38 & 178 \\
\hline 1990 & 32 & 32 & 18 & 54 & 37 & 173 \\
\hline 1991 & 7 & 34 & 19 & 49 & 35 & 144 \\
\hline 1992 & 30 & 35 & 20 & 52 & 34 & 171 \\
\hline 1993 & 9 & 36 & 18 & 56 & 32 & 151 \\
\hline 1994 & 15 & 40 & 14 & 51 & 26 & 146 \\
\hline 1995 & 16 & 38 & 15 & 42 & 27 & 138 \\
\hline 1996 & 14 & 41 & 12 & 48 & 22 & 137 \\
\hline 1997 & 15 & 44 & 15 & 46 & 22 & 142 \\
\hline 1998 & 13 & 33 & 15 & 41 & 19 & 121 \\
\hline 1999 & 15 & 37 & 16 & 51 & 21 & 140 \\
\hline 2000 & 13 & 30 & 9 & 26 & 15 & 93 \\
\hline 2001 & 15 & 40 & 15 & 49 & 18 & 137 \\
\hline 2002 & 21 & 55 & 17 & 50 & 25 & 168 \\
\hline 2003 & 22 & 50 & 21 & 53 & 19 & 165 \\
\hline 2004 & 23 & 58 & 22 & 50 & 27 & 180 \\
\hline Total & 605 & 950 & 426 & 1362 & 765 & 4108 \\
\hline
\end{tabular}

Significant differences in breeding success were detected when we compared breeding success before eradication, between sub-colonies where rats were

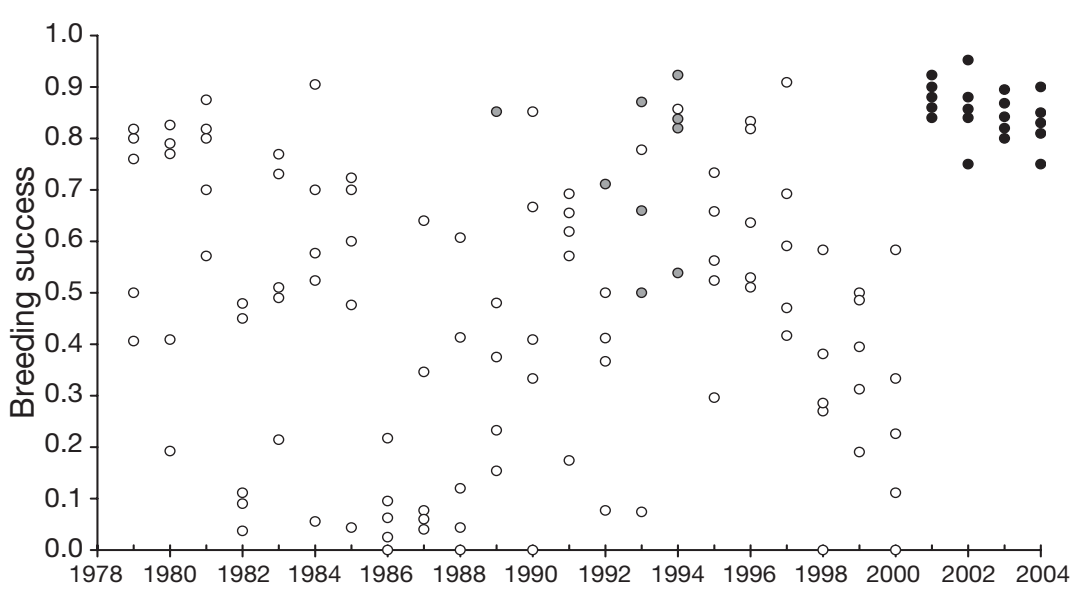

Fig. 2. Calonectris diomedea. Cory's shearwater breeding success in the 5 subcolonies under study according to year and rat management options showing breeding success at sub-colony level without rat management $(0)$, with rat control (๑) and after rat eradication $(\bullet)$ controlled and those where they were not (Table 3). We found a strong significant effect of rat management (Table 3), and a significant interaction between years and rat management, suggesting that rat impact differed according to year, presumably again in relation to rat density. After eradication (hence including the years 2001 to 2004), the model changed slightly, showing a significant interaction between rat management and sub-colony. This underlined the fact that all sub-colonies achieved higher (and more or less equal) breeding success, irrespective of year (after 2000) and sub-colony (Fig. 2). On average, breeding success doubled when rats were controlled or eradicated when compared to breeding success without rat management $(0.82 \pm 0.10 \mathrm{SD}$ compared to $0.45 \pm 0.27 \mathrm{SD})$. Moreover, rat eradication significantly improved breeding success of Cory's shearwater beyond the breeding success recorded when rats were only controlled $(0.75 \pm 0.15 \mathrm{SD}$ for control versus $0.86 \pm 0.05 \mathrm{SD}$ for eradication; $\chi^{2}=385$, $\mathrm{df}=2$, $\mathrm{p}<0.001$ ) (Fig. 2).

\section{DISCUSSION AND CONCLUSIONS}

\section{Comparing rat eradication and rat control costs}

Rat eradication on the main island and its peripheral islets, and monthly checking of permanent baitstations during the year following eradication required 1360 person-hours (trained staff). Once eradication was achieved, 8 to 16 person-hours of yearly effort (depending on whether checks were made 2 or 4 times a year) must be added for maintaining and monitoring the system. By comparison, the yearly effort needed to control the 8 sub-colonies (i.e. the whole breeding Cory's shearwater population) would vary from 1440 to 240 person-hours, depending on whether the work was performed by untrained or trained staff, respectively. The better performance of trained compared to untrained staff may seem to be a trivial result. However, many current control or eradication projects employ untrained operators. The magnitude of difference that we observed between the 2 situations should encourage managers to use only trained staff. Depending on staff experience, full eradication followed by post-eradication monitoring equates to between 1 and 5 or 6 yr of annual control. If only economic cost is taken into account, the ship rat eradication program on Lavezzu Island was more economical than the control 
Table 3. Results of Generalized Linear Models for Cory's shearwater breeding success under 2 different rat management options. ns: not significant

\begin{tabular}{|c|c|c|c|c|c|c|}
\hline \multirow[t]{2}{*}{ Factor } & \multicolumn{3}{|c|}{ Before eradication (1978-1999) } & \multicolumn{3}{|c|}{ Including eradication (1978-2004) } \\
\hline & df & $\chi^{2}$ & $\mathrm{p}$-value & df & $\chi^{2}$ & p-value \\
\hline Rat management & 1 & 26.9 & $<0.001$ & 1 & 29.7 & $<0.001$ \\
\hline Sub-colony & 4 & 132.1 & $<0.001$ & 4 & 137.2 & $<0.001$ \\
\hline Year & 21 & 457.7 & $<0.001$ & 24 & 480.4 & $<0.001$ \\
\hline Sub-colony $\times$ Rat management & 2 & 1.1 & $0.6(\mathrm{~ns})$ & 6 & 60.8 & $<0.001$ \\
\hline Year $\times$ Rat management & 3 & 13.8 & $<0.01$ & 2 & 13.7 & $<0.01$ \\
\hline
\end{tabular}

program after only 6 yr. Once again, such a result may appear trivial a posteriori, but gives an idea of the return on investment for both strategies. Moreover, the eradication strategy we used for the reasons outlined in 'Materials and methods' is fairly labour intensive compared to the improved strategy consisting of hand or aerial broadcasting of toxic baits for example (Towns \& Broome 2003). No doubt using these methods would greatly increase the economic advantages of eradication if compared to control.

\section{Comparing the ecological benefits of eradication and control}

Comparison of Cory's shearwater breeding success with (0.82) and without $(0.45$; see also Thibault 1995) rat control demonstrates the detrimental effect of these rodents. A similar increase in breeding success after rat control or eradication was previously recorded for Cory's shearwater in Cabrera Island (Balearics Archipelago; Amengual \& Aguilar 1998) and in Congreso Island (Chafarinas Islands; Igual et al. 2006). Such a result was also obtained for Audubon's shearwater Puffinus lherminieri in the Sainte-Anne islets (Martinique Island, French West Indies) where breeding success increased from 0 before eradication to $85-90 \%$ after eradication (Pascal et al. 2003). During the $4 \mathrm{yr}$ following Lavezzu ship rat eradication, breeding success was not only higher, but also more homogeneous among sub-colonies and years compared to previous years without rat management (coefficient of variation, $\mathrm{CV}=6.8$ vs. $63.9 \%$ ). Moreover, breeding success was significantly $(11 \%)$ higher when rats were eradicated than when rats were only controlled, suggesting that control did not totally prevent the detrimental effects of rats. Igual et al. (2006) observed similar variation of Cory's shearwater breeding success among subcolonies of the Chafarinas Islands despite rat control. They suggested that rat impact differed among the 2 investigated habitats, being higher in vegetated than in rocky habitats. As all of the Cory's shearwater subcolonies of Lavezzu Island are located in rocky habitats, the explanation given for Chafarinas Islands is inconsistent with our results for Lavezzu. Nevertheless, variations in rat density or in rat predation behaviour identified by Igual et al. (2006) were attributed to variations in breeding site anti-predation quality. Igual et al. (2007) explained these variations in their 'evolutionary trap' theory, which may explain variation of Cory's shearwater breeding success among Lavezzu Island sub-colonies. The great variation of breeding success among years and sub-colonies without rat control suggests that measuring rat impact on reproductive success of seabird colonies in such situations requires several years of data. Data collected during 1 yr alone may lead to the wrong conclusion, for example that rats have no impact.

In the medium term, additional positive effects are expected from rat eradication. Examples include an indirect effect of increasing breeding success on mate fidelity, as found by Thibault (1994) for Cory's shearwater and Bried \& Jouventin (1999) for white-chinned petrel Procellaria aequinoctialis, or an increase in the number of breeding pairs through either immigration or better local recruitment. However, the last scenario would require about $10 \mathrm{yr}$, given the fledglings' long delayed sexual maturation (Thibault et al. 1997). It is also likely that pairs prevented from breeding early in the season because of disturbance by rats, will now be able to breed on the rat-free island, and that further nesting places which were previously unsuitable because of the presence of rats will now be available.

\section{Long-term strategy: balancing costs and benefits}

Many Cory's shearwater colonies are currently under pressure from ship rats or other alien mammals (Martin et al. 2000). Published breeding success assessments are thus usually rather low (but see Bayle \& Fernandez (1992) for Frioul Island off Marseilles, with a value of $0.85, \mathrm{n}=321$ ). Breeding success on the mammal-free Selvagem Islands (Madeira Archipelago, Atlantic Ocean) is also low $(0.59, \mathrm{n}=3289$; Mougin et al. 1993), but here the low rates are related to predation by yellow-legged gulls Larus cachinnans. Although ship rats have been present on Lavezzu for a 
long time, the Cory's shearwater breeding population has survived and remained stable during the last $25 \mathrm{yr}$ (Thibault \& Bonaccorsi 1999). Although they reduced breeding success, rats did not induce local extinction of the species. Until recently, the great auk Pinguinus impennis was the only western Palaearctic seabird known to have become extinct in the past $1000 \mathrm{yr}$ (Fuller 2000) and to have disappeared from western Europe since the Bronze Age (Lehnebach 2003, Pascal et al. 2006). Since, despite the long-standing and widespread introduction of rats (Alcover et al. 1992, Milberg \& Tiberg 1993, Vigne et al. 1997, Zotier et al. 1999), no western Palaearctic seabird has been recorded as extinct. But very recently, Rando \& Alcover (2007) showed that the Lava shearwater Puffinus olsoni, which was endemic to the Canary Islands, was still present between 1240 and $1475 \mathrm{AD}$ and became extinct after Europeans reached the archipelago in the early 14 th century. Rando \& Alcover (2007) strongly suggest that Europeans and species they introduced, such as rats, cats and mice, accelerated initial declines induced by earlier inhabitants who arrived before 2000 BC. However, there are many Mediterranean islands that are currently inhabited by both rats and Cory's shearwaters (see references in Martin et al. 2000), thus suggesting that Cory's shearwater is an atypical and interesting model. However, the Lava shearwater example shows that extinction may be induced by the sum of several aggressive events distributed along time, the last one being often the only one documented. As Mediterranean islands are currently under increasing pressure from various human activities, such a scenario may occur within a brief period of time, and any management operations that improve population health must be promoted.

Our cost-benefit comparison strongly suggests that eradication is preferable to control. Moreover, eradication provides additional advantages, since it affects other organisms such as ground-nesting birds, reptiles, insects, snails, and plants, which unlike Cory's shearwater, are actually eliminated by rats. It thus provides a new island for colonisation by locally extinct or endangered species that cannot sustain their populations if rats are present. For example, although founding new populations could be a long process for long-lived colonial birds, several Mediterranean species, such as pallid swift Apus pallidus, storm petrel Hydrobates pelagicus or Mediterranean shearwater Puffinus yelkouan may be candidates for increasing or establishing populations in Lavezzu Island. Furthermore, eradication requires only one, admittedly major, ecosystem disturbance, whereas partial control produces detrimental effects annually. Finally, eradication requires a single effort, in contrast to the perennial financial support required to perform yearly control operations.
Another issue that must be considered when weighing up the benefits of eradication and control is the potential emergence of rodenticide resistance during long-term control campaigns. Such resistance appeared 11 yr (1958) after the first use of warfarin, the first anticoagulant rodenticide (Lund 1964, Greaves 1971, Jackson et al. 1975). Moreover, resistance appeared again when the second-generation anticoagulants were used (Lund 1984, Greaves 1994). Relationships have been documented between resistance and genetics (Greaves et al. 1977), resistance and reproduction (Bishop et al. 1977, Partridge 1979), and resistance and an increase in the need for vitamin $\mathrm{K}$ in resistant rodents (Greaves 1994). These relationships suggest that resistance is potentially present in every rodent population, thanks to the coevolution between plants that produce anticoagulants such as coumarin and rodent consumers. This resistance can nullify the benefits of control and limits options to plan for future eradication.

One final issue to be considered is the risk that rats may recolonise after eradication. On Lavezzu Island, this risk may be high, owing to the disembarkation of ca. 150000 tourists per year, and the anchoring of ca. 4000 ships in summer. To deal with this, we suggested establishing a rat-proof wharf and a permanent baitstation system. The recolonisation issue also means that choosing between control and eradication must take into account the risk of reintroduction by humans, and we advise that eradication in areas where human pressure is high (i.e. many small and medium-sized Mediterranean islands) should be chosen only for protected and actively managed areas. Indeed, when eradication is not feasible, control remains a useful management tool.

Acknowledgements. The eradication operation was supported financially by the Office de l'Environnement de la Corse through a contract with Institut National de la Recherche Agronomique. We warmly thank Jean-Claude Thibault, who provided the 25 years breeding success data on Cory's shearwater, information about control operations, and many details on the local and general biology of this seabird species. We thank the rangers of Groupement Atlantique des Brigades Mobiles d'Intervention de l'Office National de la Chasse et de la Faune Sauvage and the International Marine Park of Bonifacio Strait staff for rat eradication operations conducted in autumn 2000. We are very grateful to David Towns, who improved the English and suggested several ways of improving the discussion and conclusion.

\section{LITERATURE CITED}

Abdelkrim J, Pascal M, Calmet C, Samadi S (2005a) Importance of assessing population genetic structure prior to eradication of invasive species: examples from insular Norway rat populations. Conserv Biol 19:1509-1518 
Abdelkrim J, Pascal M, Samadi S (2005b) Island colonization and founder effects: the invasion of Guadeloupe islands by ship rats (Rattus rattus). Mol Ecol 14:2923-2931

Abdelkrim J, Pascal M, Samadi S (2007) Establishing causes of eradication failure based on genetics: case study of ship rat eradication in Ste. Anne archipelago. Conserv Biol 21(3):719-730

Alcover JA, Florit F, Mourer-Chauviré C, Weessie PDM (1992) The avifaunas of the isolated Mediterranean islands during the Middle and Late Pleistocene. Nat Hist Mus Los Ang Cty Contrib Sci 36:273-283

Amengual JF, Aguilar JS (1998) The impact of the Black rat Rattus rattus on the reproduction of Cory's shearwater Calonectris diomedea in the Cabrera national park, Balearic Islands, Spain. In: Écologie des oiseaux marins et gestion intégrée du littoral en Méditerranée. Arcs Editions, Tunis, p 94-121

Atkinson IAE (1985) The spread of commensal species of Rattus to oceanic islands and their effect on island avifaunas. In: Moors PJ (ed) Conservation of island birds. International Council for Bird Preservation, Technical Publication, Cambridge, p 35-81

Atkinson IAE (1989) Introduced animals and extinctions. In: Western D, Pearl MC (eds) Conservation for the twentyfirst century. Oxford University Press, Oxford, p 54-75

Atkinson IAE (2001) Introduced mammals and models for restoration. Biol Conserv 99:81-96

Audouin-Rouzeau F (2003) Les chemins de la peste: le rat, la puce et l'homme. Presses Universitaires de Rennes, Rennes

Audouin-Rouzeau F, Vigne JD (1994) La colonisation de l'Europe par le rat noir (Rattus rattus). Rev Paleobiol 13:125-145

Bayle P, Fernandez O (1992) Protection of Cory's shearwater Calonectris diomedea by limitation of a population of feral rabbit Oryctolagus cuniculus on Frioul Archipelago (Marseilles, France). Avocetta 41:165-167

Bell BD (1978) The Big South Cape Islands rat irruption. In: Dingwall PR, Atkinson I A E, Hay C (eds) The ecology and control of rodents in New Zealand nature reserves. Department of Land and Survey, Wellington, p 33-45

BirdLife International (2000) Threatened birds of the world. Lynx Edicions and BirdLife International, Barcelona and Cambridge

Bishop JA, Hartley DJ, Partridge GG (1977) The population dynamics of genetically determined resistance to warfarin in Rattus norvegicus from Mid Wales. Heredity 39: 389-398

Bried J, Jouventin P (1999) Influence of breeding success on fidelity in long-lived birds: an experimental study. J Avian Biol 30:392-398

Buckner CH (1957) Population studies on small mammals of southeastern Manitoba. J Mammal 38:87-97

Calmet C, Pascal M, Samadi S (2001) Is it worth eradicating the invasive pest Rattus norvegicus from Molène archipelago? Genetic structure measures as a decision-making tool. Biodivers Conserv 10:911-928

Cariton JT (1987) Patterns of transoceanic marine biological invasions in the Pacific Ocean. Bull Mar Sci 41:452-465

Cariton JT, Geller JB (1993) Ecological roulette: the global transport of non-indigeneous marine organisms. Science 261:78-82

Ceballos G, Brown JH (1995) Global patterns of mammalian diversity, endemism and endangerment. Conserv Biol 9:559-568

Chapuis JL, Barnaud G, Bioret F, Lebouvier M, Pascal M (1995) L'éradication des espèces introduites, un préalable à la restauration des milieux insulaires. Cas des îles françaises. Natures Sciences et Sociétés (hors série) 3:51-65

Clavero M, García-Berthou E (2005) Invasive species are a leading cause of animal extinctions. Trends Ecol Evol 20:110

Courchamp F, Langlais M, Sugihara G (1999) Protecting birds: modelling the mesopredator release effect. J Anim Ecol 68:282-292

Courchamp F, Chapuis JL, Pascal M (2002) Mammal invaders on islands: impact, control and control impact. Biol Rev Camb Philos Soc 78:347-383

Daycard L, Thibault JC (1990) Gestion de la colonie de Puffin cendré (Calonectris diomedea) de l'île Lavezzi (Corse): une expérience de dératisation. Travaux Scientifiques du Parc National and Réserves Naturelles de Corse. Trav Sci Parc Natl Res Nat Corse (Ajaccio) 28:55-71

Diamond J (1989) Overview of recent extinctions. In: Western D, Pearl MC (eds) Conservation for the twenty-first century. Oxford University Press, Oxford, p 37-41

$>$ Diamond JM, Veitch CR (1981) Extinctions and introductions in the New Zealand avifauna: cause and effect? Science 211:499-501

> Donlan CJ, Wilcox C (2007) The complexities of costing eradications. Anim Conserv 10:154-158

Ebenhard T (1988) Introduced birds and mammals and their ecological effects. Swed Wildl Res Viltrevy 13:5-107

Flux JEC (1994) World distribution. In: Thomson HV, King CM (eds) The European rabbit: the history and biology of a successful colonizer. Oxford University Press, Oxford, p 8-21

Fuller E (2000) Extinct birds. Oxford University Press, Oxford - Greaves JH (1971) Resistance to anticoagulant in rodents. Pestic Sci 2:276-279

Greaves JH (1994) Resistance to anticoagulant rodenticides. In: Buckle AP, Smith RH (eds) Rodent pests and their control. CAB International, Wallingford

Greaves JH, Redfern R, Ayres PB, Gill JE (1977) Warfarin resistance: a balanced polymorphism in the Norway rat. Genet Res Camb 30:257-263

Groombridge B (ed) (1992) Global biodiversity. Chapman \& Hall, London

Gurevitch J, Padilla DK (2004) Are invasive species a major cause of extinctions? Trends Ecol Evol 19:470-474

Hodges CSN, Nagata SR (2001) Effects of predator control on the survival and breeding success of the endangered Hawaiian dark-rumped petrel. In: Scott JM, Conant S, Van Riper C (eds) Evolution, ecology, and management of Hawaiian birds: a vanishing avifauna. Studies in Avian Biology No. 22. Cooper Ornithological Society, p 308-318

Honegger RE (1981) List of amphibians and reptiles either known or thought to have become extinct since 1600. Biol Conserv 19:141-158

> Howald G, Donlan CJ, Galván JP, Russell JC and others (2007) Invasive rodent eradication on islands. Conserv Biol 21:1258-1268

Hulme PE (2003) Biological invasions: winning the science battles but losing the conservation war? Oryx 37:178-193

Igual JM, Forero MG, Gomez T, Orueta JF, Oro D (2006) Rat control and breeding performance in Cory's shearwater (Calonectris diomedea): effects of poisoning effort and habitat features. Anim Conserv 9:59-65

Igual JM, Forero MG, Gomez T, Oro D (2007) Can an introduced predator trigger an evolutionary trap in a colonial seabird? Biol Conserv 137:189-196

Jackson WB, Brooks JE, Bowerman AM, Kaukeinen DE (1975) Anticoagulant resistance in the Norway rat. Pest Control 43(4):12-16 
King WB (1985) Island birds: will the future repeat the past? In: Moors PJ (ed) Conservation of island birds. International Council for Bird Preservation, Technical Publication, Cambridge, p 3-15

Lehnebach C (2003) La grotte du Phare (Biarritz, PyrénéesAtlantiques). Origine des assemblages fuaniques, du Néolithique récent/final au premier Age du Fer, étude archéozoologique. MS thesis, Université Panthéon-Sorbonne (Paris I)

Lever C (1994) Naturalized animals: the ecology of successfully introduced species. Poyser Natural History, London

- Lorvelec O, Pascal M (2005) French alien mammal eradication attempts and their consequences on the native fauna and flora. Biol Invasions 7:135-140

Lund M (1964) Resistance to warfarin in the common rat. Nature 203:778

Lund M (1984) Resistance to the second-generation anticoagulant rodenticides. In: Clark DO (ed) Proc 11th Vertebrate Pest Conference. University of California, Davis, p 89-94

MacMichael AJ, Buma MJ (2000) Global change, invasive species, and human health. In: Mooney HA, Hobbs RJ (eds) Invasive species in a changing world. Island Press, Washington, DC, p 191-210

Martin JL, Thibault JC, Bretagnolle V (2000) Black rats, island characteristics and colonial nesting birds in the Mediterranean: current consequences of an ancient introduction. Conserv Biol 14:1452-1466

McClelland P, Tyree P (2002) Eradication: the clearance of Campbell Island. NZ Geog 58:86-94

Milberg P, Tiberg T (1993) Naïve birds and noble savages: a review of man-caused prehistoric extinctions of island birds. Ecography 16:229-250

Mooney HA, Hobbs RJ (2000) Global change and invasive species: Where do we go from here? In: Mooney HA, Hobbs RJ (eds) Invasive species in a changing world. Island Press, Washington, DC, p 425-434

Mougin JL, Jouanin C, Roux F, Zino F (1993) Les paramètres conditionnant la réussite de la reproduction chez le puffin cendré Calonectris diomedea borealis de Selvagem Grande. Rev tr Ornithol 63:202-215

Nunn PD (1994) Oceanic Islands. The Natural Environment Series. Blackwell, Oxford

OTA (Office of Technology Assessment) (1993) Harmful nonindigenous species in the United States. OTA-F-565. US Government Printing Office, Washington, DC

Palmer M, Pons GX (1996) Diversity in western Mediterranean islets: effects of rat presence on a beetle guild. Acta Oecol 17:297-305

Palmer M, Pons GX (2001) Predicting rat presence on small islands. Ecography 24:121-126

Partridge GG (1979) Relative fitness of genotype in population of Rattus norvegicus polymorphic for warfarin resistance. Heredity 43:239-246

Pascal M, Chapuis JL (2000) Éradication de mammifères introduits en milieux insulaires: questions préalables et mise en application. Rev Ecol (Terre Vie) (Suppl 7):85-104

Pascal M, Siorat F, Cosson JF, Burin des Roziers H (1996) Éradication de populations insulaires de Surmulot (Archipel des Sept-Îles - Archipel de Cancale: Bretagne, France). Vie Milieu 46:267-283

Pascal M, Brithmer R, Lorvelec O, Vénumière N (2003) Conséquences sur l'avifaune nicheuse de la réserve naturelle des Îlets de Sainte-Anne (Martinique) de la récente invasion du rat noir (Rattus rattus), établies à l'issue d'une tentative d'éradication. Rev Ecol Terre Vie 59:309-318

Pascal M, Siorat F, Lorvelec O, Yésou P, Simberloff D (2005) A pleasing Norway rat eradication consequence: two shrew species recover. Divers Distrib 11:193-198

Pascal M, Lorvelec O, Vigne JD (2006) Invasions biologiques et extinctions: 11000 ans d'histoire des vertébrés en France. Coédition Belin/Quæ, Paris, p 1-350

Penloup A, Martin JL, Gory G, Brunstein D, Bretagnolle V (1997) Nest site quality and nest predation as factors explaining the distribution of Pallid swifts (Apus pallidus) on Mediterranean islands. Oikos 80:78-88

Perrings C, Williamson M, Dalmazone S (2000) The economics of biological invasions. Edward Elgar, Cheltenham

Pimentel D (2002) Biological invasions: economic and environmental costs of alien plant, animal, and microbe species. CRC Press, Boca Raton, FL

> Pimentel D, Lach L, Zuniga R, Morrison D (2000) Environmental and economic costs of nonindigenous species in the United States. Bioscience 50:53-65

Pimentel D, Zuniga R, Morrison D (2005) Update on the environmental and economic costs associated with alien-invasive species in the United States. Ecol Econ 52:256-288

Rando JC, Alcover JA (2007) Evidence for a second western Palaearctic seabird extinction during the last Millennium: the Lava shearwater Puffinus olsoni. Ibis 150:188-192(5) doi: 10.1111/j.1474-919x.2007.007411.x

Ruiz GM, Cariton JT, Grosholz ED, Hines AH (1997) Global invasions of marine and estuarine habitats by non-indigenous species: mechanisms, extent and consequences. Am Zool 37:621-632

Ruiz GM, Rawlings TK, Dobbs FC, Drake LA, Mulady T, Huq A, Colwell RR (2000) Global spread of microorganisms by ships: ballast water discharged from vessels harbours a cocktail of potential pathogens. Nature 408:49-50

Sax DF, Stachowicz JJ, Brown JH, Bruno JF and others (2007) Ecological and evolutionary insights from species invasions. Trends Ecol Evol 22:465-471

Simberloff D (2001) Eradication of island invasives: practical actions and results achieved. Trends Ecol Evol 16:273-274

Simberloff D (2002) Today Tiritiri Matangi, tomorow the world! Are we aiming too low in invasives control? In: Veitch CR, Clout MN (eds) Turning the tide: the eradication of invasive species. IUCN, The World Conservation Union, Cambridge, p 4-12

Taylor RH, Thomas BW (1993) Rats eradicated from rugged Breaksea Island (170 ha), Fiordland, New Zealand. Biol Conserv 65:191-198

- Taylor RH, Kaiser GW, Drever MC (2000) Eradication of Norway rats for recovery of seabird habitat on Langara Island, British Columbia. Restor Ecol 8:151-160

Thibault JC (1994) Nest-site tenacity and mate fidelity in relation to breeding success in Cory's shearwater Calonectris diomedea. Bird Study 41:25-28

Thibault JC (1995) Effect of predation by the black rat Rattus rattus on the breeding success of Cory's shearwater Calonectris diomedea in Corsica. Mar Ornithol 23:1-10

Thibault JC, Bonaccorsi G (1999) The birds of Corsica. An annotated checklist. BOU Checklist series 17. British Ornithologists' Union (BOU), Tring

Thibault JC, Delaugerre M, Cheylan G, Guyot I, Miniconi R (1987a) Les vertébrés terrestres non domestiques des îles Lavezzi (sud de la Corse) Part I. Bull Mens Soc Linn Lyon, 56:73-103

Thibault JC, Delaugerre M, Cheylan G, Guyot I, Miniconi R (1987b) Les vertébrés terrestres non domestiques des îles Lavezzi (sud de la Corse). Part II. Bull Mens Soc Linn Lyon 56:117-152

Thibault JC, Bretagnolle V, Rabouam C (1997) The Cory's shearwater (Calonectris diomedea). BWP Update. The Journal of Birds of the Palearctic 1:75-98 
Towns DR, Ballantine WJ (1993) Conservation and restoration of New-Zealand island ecosystems. Trends Ecol Evol 8:452-457

Towns DR, Broome KG (2003) From small Maria to massive Campbell: forty years of rat eradications from New Zealand islands. NZ J Zool 30:377-398

Veitch CR, Clout MN (eds) (2002) Turning the tide: the eradication of invasive species. World Conservation Union, Gland

Vigne JD (1999) The large 'true' Mediterranean islands as a model for the Holocene human impact on the European vertebrate fauna? Recent data and new reflections. In: Benecke $\mathrm{N}$ (ed) The Holocene history of the European vertebrate fauna. Modern aspects of research. Deutsches Archäologisches Institut, Eurasien-Abteilung, Berlin, p 295-322

Vigne JD, Granjon L, Auffray JC, Cheylan G (1994a) Les micromammifères. In: Vigne JD (ed) L'île Lavezzi. Hommes, animaux, archéologie et marginalité (XIIIe-XXe siècles, Bonifacio, Corse), Vol 13. Monogr Centre de Recherches Archéologiques. CNRS, Paris, p 133-154

Vigne JD, Thibault JC, Cheylan G (1994b) Les effets des activ-

Editorial responsibility: Rory Wilson,

Swansea, UK ités humaines sur certains peuplements de l'île Lavezzi: mammifères, oiseaux, invertébrés. In: Vigne JD (ed) L'île Lavezzi. Hommes, animaux, archéologie et marginalité (XIIIe-XXe siècles, Bonifacio, Corse), Vol 13. Monogrtre de Recherches Archéologiques, CNRS, Paris, p 235-243

Vigne JD, Bailon S, Cuisin J (1997) Biostratigraphy of amphibians, reptiles, birds and mammals in Corsica and the role of man in the Holocene faunal turnover. Anthropologica 25-26:587-604

Vitousek PM, Mooney HA, Lubchenco J, Melillo JM (1997) Human domination of Earth's ecosystems. Science 277: 494-499

Warham J (1996) The behaviour, population biology and physiology of the petrels. Academic Press, London

Whittaker RJ (1998) Island biogeography. Ecology, evolution, and conservation. Oxford University Press, Oxford

Wilson EO (1993) La diversité de la vie. Odile Jacob, Paris

Zotier R, Bretagnolle V, Thibault JC (1999) Biogeography of the marine birds of a confined sea, the Mediterranean. J Biogeogr 26:297-313

Submitted: September 7, 2007; Accepted: January 8, 2008 Proofs received from author(s): March 10, 2008 